\title{
THE PERCEPTION OF THE PROFESSIONAL SELF OF SOCIAL WORKERS IN PRIVATE PRACTICE
}

\section{Davidson, CJ Schenck}

\section{INTRODUCTION}

Earl Babbie (1992:251) states that "...who we think we are - our self concept - and how we behave is largely a function of how others see and treat us". He goes on to say that "...the way others perceive us is largely conditioned by expectations they may have in advance". This exploratory research focuses on social workers in private practice - how they view their professional selves, the factors that contribute to the development of their professional selves and the factors that hinder or facilitate this development.

\section{DESCRIPTION OF THE CONCEPT "PROFESSIONAL SELF"}

The Concise Oxford Dictionary defines "professional" as "of, belonging to, connected with a profession". In this study the term "the professional self" may be understood as the way in which the social worker or practitioner in private practice views him/herself as a professional person offering and delivering a certain service to the public. The respondents gave a variety of descriptions of how they perceived their professional selves.

The professional self is that part of the social worker that is guided and informed by the values, ethics and principles of the social work profession. It represents a way of conducting oneself as a social worker. The manner or style in which this is done is informed by the personality and creates a certain image which is presented to the public and communicates a message of who this professional person is.

The professional self is also that part of the social worker in private practice that has acquired knowledge, skills and experience used in the rendering of the service offered. These skills include, amongst other things, counselling expertise, and organisational and managerial abilities. The professional self aims to be trustworthy, reliable, responsible and accountable. The professional self engages in self-evaluation and personal growth on an ongoing basis. The professional self has the clients' interests at heart and regards human beings as valuable and worthy of dignity, respect and the right to be self-determining.

\section{THEORETICAL FOUNDATION OF THE STUDY}

The concepts of modern and postmodern paradigms (Anderson, 1997; Held, 1995; Kvale, 1992), Rogerian theory (Rogers, 1951, 1978; Grobler, Schenck \& Du Toit, 2003), constructivist philosophy and social construction theory (Efran, Lukens \& Lukens, 1988; Hayley, 2002; Real, 1990; Watzlawick, 1984) have been utilised in this research to assist in explaining the development of the self-concept and the construction of perceptions of themselves as social work professionals. The only literature found on the perceptions of the social workers by the public were works by Freeman and Valentine (2004), Gibelman (2004), Schenck (2003), Ungar (2004) and Winston, Stinson and Stinson (2004); this study will hopefully lead to further exploration of this important aspect.

The theories mentioned above will be explained briefly in the sections that follow.

\section{Rogerian theory}

Rogers does not present the self-concept "as a little man in the head" who controls a person's behaviour; he sees it as representing the person's conscious experience of himself or herself (Meyer, Moore \& Viljoen, 1989:379). According to Rogers (1951:501), the self-concept is an 
organised configuration of perceptions of the self which is admissible to awareness. An individual's perceptions of the self are formed in relation to others and to the environment through experiences and the meaning that the individual attaches, both positive and negative, to the experience or object (see also Grobler et al., 2003).

\section{Constructivism}

Constructivism is a philosophy that explores constructed reality. The world we live in is invented, not discovered (Anderson, 1997:23; Real, 1990:257). "Constructivists acknowledge the active role they play in creating a view of the world and interpreting observations in terms of it" (Efran etal., 1988:29).

Constructivism is not a description of any outside objective reality. There is no fixed reality, but it is rather the acquisition of knowledge constructed on the basis of personal experience. Each individual is responsible for the construction of his/her own reality. Thus autonomy implies responsibility - "if I am the one who decides how I will act, then I am responsible for my action" (Watzlawick, 1984:59).

\section{Social construction theory}

According to Freedman and Combs (in Hayley, 2002:24-25), there are four main ideas inherent in a social constructionist world view:

- realities are socially constructed;

- realities are constituted through language;

- realities are organised and maintained through narrative;

- there are no essential truths.

Knowledge, including self-knowledge, is a social construction, a product of social exchange, and the locus of knowledge lies in the relationship (Anderson, 1997:41).

Thus through the interviews conducted with the social workers in private practice, meaning is constructed between the researcher and the interviewee as to how the interviewee experiences him/herself in private practice and how the researcher experiences herself in relation to each interviewee and to the interviewees as a whole, and how they in turn experience the researcher.

\section{THE RESEARCH PROCESS}

\section{Problem statement and research question}

The perception of the professional self of social workers in private practice, i.e. the social worker's self-concept in relation to his/her profession, impacts directly on the quality and effectiveness of service delivery and the ability to be appropriately remunerated. The question asked in this research was the following: What are the perceptions of the professional self of the social worker in private practice and how do these perceptions affect the social workers' experience of status and service delivery?

\section{Research design}

The research design explains how the research study was conducted in order to fulfil the objectives (Rubin \& Babbie, 1993:330). This study used a qualitative and exploratory research design to describe the co-constructed viewpoint and experience of the respondents in question, namely social workers in private practice. 
Exploratory research entails commencement in the exploration of a relatively unknown research area (Mouton \& Marais, 1991:43; Rubin \& Babbie, 1993:107). Rubin and Babbie state that exploratory studies help to break new ground and yield new insights and understandings. The researchers and respondents created or co-constructed a general picture of the conditions that contribute to the perception of the professional self of social workers in private practice.

\section{Method of data collection}

Producing an interview schedule or guide (based on the researcher's ideas) forces the researcher to think explicitly about what he/she hopes the interview might cover (De Vos, Strydom, Fouche \& Delport, 2005:296). After a survey of the relevant literature, consultation with academic experts and through the observations of the researcher, an interview guide was constructed for the interviews with the respondents (i.e. social workers in private practice living in Johannesburg). This guide ensured that the same topics were addressed and explored in each interview in order to minimise the chance of omitting any material.

\section{Method of data presentation}

The data collected through the interviews with the respondents were analysed for similarities, differences and themes (Rubin \& Babbie, 1993:387). Inductive abstraction and generalisation were utilised to analyse and interpret the data, resulting in a more systematic explanation of the topic. Inductive logic is well suited to exploratory and descriptive research (Mouton \& Marais, 1991:103). Tentative conclusions may provide a possible conceptual framework for further research.

\section{Research population and sampling procedure}

The respondents in this study were a sample of social workers in private practice selected from the population of social workers in private practice in the Johannesburg area. The 2005 resource book for the South African Association of Social Workers in Private Practice (SAASWIPP) was the sampling frame used to access the population of social workers living in Johannesburg. There were inaccuracies in the resource book, e.g. incorrect telephone numbers or numbers that did not exist, but as non-probability purposive sampling was the sampling method used in the research, the lack of representativeness as a result of these inaccuracies was not problematic.

The total population for the study included all the social workers in private practice in Johannesburg. This population of approximately 125 social workers was too large for the purposes of this exploratory study and interviewing them all would not have been feasible. A nonprobability purposive sample of the population was therefore selected. Although non-probability sampling methods are generally regarded as less reliable than probability sampling (which is more representative of the population), they are usually easier and less expensive to use (Rubin \& Babbie, 1993:259). This qualitative research of limited scope was feasible utilising a sample of 12 respondents $(\mathrm{N}=12$ or $10 \%$ of the population). It was regarded as sufficient for an exploratory study as basis for further research.

\section{Pilot study of interview guide}

One pre-test was conducted. It was determined by the pre-test respondent and the researcher that the interview should be one hour in duration. A longer interview would not have been feasible as the respondents were unable to spare the researcher more time. As the respondents work for themselves, there would have been a cost implication for them, i.e. "time is money". 


\section{RESEARCH FINDINGS}

\section{Profile of the respondents}

\section{Gender}

Only one $(8.3 \%)$ out of the twelve social workers interviewed was male. There were three male social workers in the Johannesburg area listed in the SAASWIPP 2005 resource book, two of whom were not in private practice. This statistic echoes the relatively small number of males in the profession as a whole as "social work is globally a female-dominated profession" (Schenck, 2003:10).

\section{Age}

TABLE 1

AGE

\begin{tabular}{|c|c|c|}
\hline Age & Frequency & Percentage \\
\hline $30-39$ & 1 & 8.3 \\
$40-49$ & 4 & 33.3 \\
$50-59$ & 4 & 33.3 \\
$60-69$ & 1 & 8.3 \\
$70-79$ & 2 & 16.8 \\
\hline Total & 12 & 100 \\
\hline
\end{tabular}

The average age of the social workers in this study is 53, the youngest person being 39 and the oldest being 75. Ten of these social workers worked in the broader social work field to gain experience and to build their knowledge base before entering into private practice and were in their thirties and older when they commenced private practice. Two of the respondents entered into private practice immediately after qualifying. Both of them were more mature (in age) students when they studied social work, had life experience and worked in agencies while building up their practices.

Two of the respondents (or 16.8\%) who fell in the 70-79 age category, when most people are retired, are still working in private practice. Each of them started private practice in their fifties, almost as a "second career", their private practices flowing from the work they were doing previously.

\section{Language}

The majority (75\%) of respondents in the study speak English and, although the remainder (25\%) speak either Afrikaans or South Sotho, they mostly counsel or conduct their business in English.

\section{Marital status}

The majority $(75 \%)$ of the respondents were married with or without children. Only one respondent did not have children $(8.3 \%)$. For the married respondents, having a spouse to contribute to the finances of the family allowed them to be more flexible in the amount of work they did and hence the amount of money they generated, especially whilst raising their children. There is more financial pressure on the three single social workers $(25 \%)$ as sole supporters of their families.

\section{Number of years in private practice}

The average number of years in private practice in this study is 12.45 , with the lowest being 3.5 and the highest being 22 . These private practitioners are very experienced, especially when their 
previous work experience (before entering private practice) is taken into consideration. Taken together with their life experience, they have a wealth of knowledge and expertise in their chosen careers.

\section{Part-time/full-time private practice}

In this study the term part-time means working between two to four hours per day and the term full-time means working between five to eight hours per day.

Although there are more full-time private practitioners $(83.3 \%)$ in this study than part-time private practitioners $(16.7 \%)$, it appears from the SAASWIPP 2005 resource book that there are probably more part-time private practitioners overall. Many social workers in private practice continue to work at an agency or institution whilst they build up their practices. Of the private practitioners interviewed, not one mentioned working for a company or corporation. One respondent, who specialises in education and training, has corporate clients.

\section{Educational qualifications}

Fifty percent $(50 \%)$ of these social workers have undergraduate degrees and $50 \%$ have postgraduate degrees. The SAASWIPP resource book reflects that more private practitioners have undergraduate degrees than postgraduate degrees. This result was different from what was anticipated. The researchers anticipated that more social workers in private practice would have postgraduate qualifications.

\section{Aspects that influenced the perceptions of the professional self of the social workers in private practice}

\section{Motivation for choosing social work}

The respondents had different motivations for becoming a social worker, ranging from knowing since childhood that they wanted to be a social worker to those who actually wanted to be psychologists or medical doctors, but opted for social work as they were not sure that they would be selected, or they could not afford the long period of studies One respondent's mother was a social worker and she was raised in a context of helping and reaching out to others. It seemed natural for her to continue in her mother's footsteps to facilitate the empowerment of others. Two of the respondents thought that their childhood experiences and responsibilities, and the way in which they were raised contributed to the way that they saw themselves as professional social workers in private practice.

Despite their original motivation, every one of the respondents reported that they experienced job satisfaction and were happy to be contributing to the world in a positive way, no matter how small that may be. Thus it seems that their choice of social work as a profession is well suited to, and is in harmony with, their life philosophies and values that enhance their perceptions of the professional self in a positive manner.

\section{Education and training}

All the respondents acknowledged that the education and training that they had received from their respective universities laid the foundation for their theoretical understanding and the principles of practice. Without exception, they felt that this foundation was a base that needed to be extended.

One respondent stated that the level of education of the social worker can contribute to the development of the professional self. From the perspective of her professional self, she has gained more status and respect from friends and other professionals since obtaining her $\mathrm{PhD}$. 
Real growth and understanding began after qualifying as social workers when they commenced work in their chosen fields. The various organisations in which they worked were instrumental in facilitating their learning and growth, both personally and professionally. Not only did they increase their knowledge of theory, but perhaps more importantly, began to gain experience in integrating theory and practice.

Having a sound theoretical foundation provides the practitioner with a yardstick against which new or different theories and practices may be explored and the possibility of shifting paradigms or bringing more certainty to a particular paradigm. Increasing the depth and variety of knowledge provides the opportunity for more holistic thinking and thus the opportunity for better understanding and practice. The practitioner who is confident in his/her knowledge of theory contributes to the positive development of his/her professional self.

The respondents felt that their respective universities fell short in equipping them for private practice in some ways. They would like to see the following included in the curriculum in future in order to enhance the development of the professional self and so that the public and other professionals would respect social workers as knowledgeable and competent professionals.

1. Business management courses, including accounting, marketing, computer skills, taxation and how to deal with medical aids (see also Bloem, 2004:10).

2. Specialisations from which a student would be entitled to choose one or two. The specialisations could include such fields as adoptions, child therapy, addictions, HIV/Aids and legal social work. The respondents liked the fact that social workers have a broad knowledge base encompassing many different fields. They believed that this broad knowledge base enabled them to practise more holistically as they were constantly aware of different environments and contexts. The specialisations chosen could help them in marketing themselves as private practitioners who, for example, specialise in certain types of counselling. Again the respondents stated that offering specialisations would not only benefit social workers in private practice but all social workers.

3. Personal therapy could be a requirement for the social work degree. The respondents suggested that the universities could subsidise therapy for the students or provide therapists for the students. Ideally students should also attend personal growth groups provided throughout the year as part of the curriculum. Undergoing one's own personal therapy is important in training to be a social worker in order to have a better understanding of oneself, to become more emotionally mature and to understand what it is like to be in the client's position.

4. Professional behaviour: The respondents thought that students should be taught to regard themselves as capable and worthwhile, thereby enabling the growth and realisation of their potential. Together with therapy and personal growth groups, classes or workshops on how to be a professional could aid social workers to foster an attitude of being responsible for their own continued growth and learning both personally and professionally. This in turn could help social workers to gain an improved image of themselves and of the profession.

\section{Theory, models, techniques utilised in private practice}

According to the respondents, the following theories, models and techniques were utilised by them: psychoanalysis, Egan's Problem-solving model, narrative approach, transactional analysis, IMAGO, Jung, hypnotherapy, Rogers, inner child work, Erickson, cognitive/behavioural, gestalt, meditation, dream work, systems theory and spiritual work. 
Each respondent had a few different theories that he/she knows and understands well. Having a choice of theories, models and techniques for practice allows the practitioner to choose from his/her repertoire to find the theory or combination of theories and practices that most suits the social worker. All the respondents have increased their knowledge, experience and expertise since qualifying as social workers through attendance of courses, training sessions or further studies, and they feel competent and confident.

\section{Keeping abreast of new developments}

The respondents are all aware of the importance of keeping abreast of new information and take responsibility for updating themselves in this regard. They attend courses, seminars, workshops and talks. They read constantly. They attend supervision groups or have personal supervision or case consultation. They attend study groups and/or support groups. They engage in consultation with colleagues. Approximately half $(50 \%)$ of the respondents have attended their own personal therapy sessions and some of them attend therapy on an ad hoc basis. These respondents believe that therapy helps them to acquire a better understanding of themselves and, when they have greater understanding of self, they are able to have greater understanding of others and thus deliver a more effective service.

\section{Professional support assists the professional self}

Lecturers, mentors, supervisors, co-workers and colleagues all serve as role models and feedback systems for the social work student and the qualified social worker, and may influence the way in which the social worker views him/herself and his/her development. Support systems, be they personal and/or professional, can also contribute to the development of the professional self.

The respondents obtained professional support for themselves through supervision or case consultation, colleague consultation, therapy, personal growth work, being part of study/support groups, by keeping abreast of new information.

The respondents view their careers very seriously and feel responsible for maintaining and improving, where possible, their levels of expertise in their private practices so that they can feel secure in the knowledge that they are delivering an efficient and effective service to the public. They regard obtaining professional support as an essential part in the process of developing their professional selves.

\section{Spiritual belief system}

Three respondents stated that a spiritual belief system contributes to a philosophy of life and thus to the development of the personal and the professional selves. Rogers (1951:437) views a valuable contribution to the development of the professional self as the opportunity for students to formulate their own basic philosophy, for if they are to counsel others, they needs security within themselves. This security may come, in part, from having thought through some of the basic questions regarding life and tentatively formulating personally meaningful answers (Grobler et al., 2003).

\section{Professional and representative bodies}

The respondents were unanimous in their feelings regarding the role of the South African Council for Social Service Professions (SACSSP or the Council) in the development of the professional self. Regardless of the Council's mandate, the respondents stated that they felt unsupported by the Council. The respondents thought that the Council played a major role in the development of the negative view in which the social work profession was regarded by the public, as the Council according to the respondents - did nothing to promote social work, or to inform the public about 
the profession. It appeared to the respondents that the Council is not concerned about the poor image of the profession and that its status had been further lowered by introducing auxiliary social workers and thereby deprofessionalising the profession. The poor status of the profession and the often negative light in which the public and some professionals seem to regard social workers and/or the profession have an adverse effect on the way in which social workers view themselves and thus negatively influences their professional development.

Some of the respondents stated that social workers in private practice should be seen as an asset to the social work profession as they contribute towards uplifting the profession through their responsible practice, professionalism and, where possible, through correctly informing the public about the profession.

In contrast to the respondents' views of the SACSSP, they were positive and complimentary about SAASWIPP. They stated that SAASWIPP was supportive and attempted to change the public's opinion of social workers and the profession through marketing and providing information. In addition, SAASWIPP provided ongoing education and training for social workers in private practice through talks and workshops offered to the members and through their newsletter. SAASWIPP approached the medical aids and advocated social workers' rights in this regard.

\section{Public opinion and media}

The respondents were asked what they thought was the public perception of social workers and/or the profession. Although this exploratory study is researching social workers in private practice, public opinion of social workers and the profession in general has an impact on social workers in private practice.

The respondents believed that the development of the professional self was influenced by public opinion and the media - the media being a powerful tool in influencing the public. "The ways in which social work is portrayed in popular culture contribute to the shaping of the public's image of social workers, of social problems with which social workers are involved, and of the clients as consumers of social work services" (Freeman \& Valentine, 2004:151). Nieves (in Freeman \& Valentine, 2004:151) states that the public has an inaccurate image of the social work profession which has been unfairly acquired, based on misinformation, and this has been identified as a key factor in the issue concerning the low salaries of social workers.

Without exception the respondents believed that the public has a negative view of social workers in general. In their perceptions the public views social workers as welfare or statutory workers who are punitive, untrained, unprofessional lesser beings of little value. This view also emanates from other professionals, who regard social workers in a poor light.

A couple of the respondents thought that in spite of this persisting negative view of the public, there did appear to be signs of change where social workers were respected for the valuable service they rendered. They had experienced this change, for which they credited SAASWIPP, and did recognise that they also contributed to the change by rendering a high-quality service and informing the public, where possible, about social workers and the profession. When social workers perceive their professional selves as inferior they are likely to render an inferior service and reinforce the stereotypical views of the public.

Some of the respondents stated that public opinion had no impact on them and their private practice, because they took a proactive stance in marketing themselves, networking, making themselves visible and rendering a professional service. They were aware, however, as were the remaining respondents, that the image as well as the status of social workers in private practice was adversely affected by public opinion. 
They usually had to explain to their new clients the difference between social workers and psychologists and had to inform these clients about the nature of the service rendered. As the public is often not aware that social workers are engaged in private practice, social workers needed to market themselves more vigorously than psychologists. They invariably had to show psychologists and other professionals (by demonstrating their expertise over time) that they were well trained, experienced, competent practitioners who knew what they were doing.

Two of the respondents stated that there was a great deal of competitiveness amongst social workers themselves, which could be destructive to good relations and to the opinions of other professionals regarding social workers. There was an element in the profession which did not value sharing, but displayed an element of professional jealousy. One respondent said that leaving the agency where she worked in order to commence her private practice was seen as traitorous.

Two of the respondents felt inferior to psychologists at times. They said that only after many years of experience did they realise that they possessed the same skills as psychologists and more, and that they were equally competent. Only then did their perceptions of their professional selves begin to improve. They stated that, whilst they felt inferior, the quality of the service they rendered was affected. When practitioners feel inferior they more likely to allow themselves to be dictated to by others and will find difficulty in drawing boundaries.

\section{The experience of the professional self in private practice}

The respondents were asked to describe their years in private practice and how they had experienced change since entering the world of private practice to the present.

In all the description of the respondents there is a theme of the respondents' experiencing competence and confidence, personal growth, as well as job satisfaction. They have all become more experienced and increased their knowledge of self, theory and skills.

\section{Caring for the caregiver}

The respondents were asked to describe ways in which the professional cares for the professional. The following is a list of ways in which the respondents attempted to find a balance in their working lives and between their personal and professional selves: supervision, colleague interaction, therapy, spiritual practices including meditation, introspection and reflection, time management, reading, setting/maintaining boundaries, having a meaningful personal relationship, exercise including gym, yoga, walking, healthy eating, socialising, arts and crafts, gardening, listening to music, taking time out/going away.

\section{Balancing personal and professional values}

The respondents experienced very little conflict between their personal and professional values. On the rare occasion when they did discover conflict between their own and the client's values, they would refer the client to the appropriate professional. The respondents thought that being honest with themselves and knowing their own limitations were important factors in avoiding potential conflict about values.

The social work values of respecting the right of the individual to self-determination and regarding every individual as valuable and worthwhile underlies and informs the thinking and beliefs of the respondents both personally and professionally. They therefore regard difference in a client as a challenge not a threat, and they are happy to facilitate a client's finding solutions for him/herself that they themselves (the practitioners) might not choose. They do not like to impose their value systems on their clients. The respondent who works from a Christian perspective stated that she was firm with her boundaries regarding her Christian beliefs and that she did not hide this from her 
clients, but rather respected their right to decide whether or not they wanted to be counselled from this perspective.

\section{Motivation for entering private practice}

The respondents, without exception, value their autonomy and this factor, amongst others, prompted them to enter private practice. They felt that being in private practice was an opportunity to explore their creativity and to develop their skills without being hampered by the rules and regulations of bureaucracy. They value their freedom and at the same time acknowledge their responsibilities. In addition, private practice affords them the opportunity to be more adequately remunerated than what would have been the case had they still be working for the government or an NGO.

Two respondents experienced burnout in the agencies in which they were working. From their perspectives their case loads were unrealistically high and onerous, and they were unable to address these problems in a constructive manner beneficial to the clients, themselves and their agencies. They felt frustrated with bureaucracy.

Many of the respondents liked the flexibility of being in private practice. Depending on their circumstances and their needs, they were able to change from working full time to part time and from part time to full time.

All the respondents saw private practice as being financially viable and probably one of the areas in social work where the highest income could be earned. The respondents said that they were in private practice because they valued themselves as competent practitioners who could deliver a quality service and they deserved to be adequately remunerated.

\section{Primary responsibility in private practice}

Emphasis should be placed on the importance of professional, ethical practice, according to the respondents. In order to be aware of this, it is also necessary to be aware of the professional self. The respondents believed that they needed to be reliable and consistent in striving to build and maintain trust; to be a catalyst for healing; and to provide the opportunity for enabling the client to empower him/herself. As Rogers (in Rowan, 1998:67) says: "It involves an acceptance and a caring for the client as a separate person, with permission for him to have his own feelings and experiences, and to find his own meanings in them".

\section{Quality of service}

The quality of service offered is inextricably linked to the primary responsibility of the private practitioner. To the respondents it means rendering an effective, professional service that is suitable for the needs of the client, i.e. using the modalities that best suit the client; working at the level and pace of the client with empathy, genuineness and presence. Bugental (in Rowan, 1998:70) states that presence is immensely more than just being there physically. It is being totally in the situation in body, in emotions, in relating to others, in thoughts, in almost every way.

\section{Marketing}

All the respondents received clients as a result of word of mouth, implying that former clients had been satisfied with the service they received from these practitioners. As the reputation of the private practitioner grows, so too does the private practice. Respondents who marketed themselves when they first commenced private practice, no longer need to do this as they have established viable practices. 


\section{SUMMARY}

The private practitioners interviewed for this study view themselves as experienced, competent and responsible individuals offering an effective service to the public and thereby contributing to the improvement of quality of life of their clients. They believe that they contribute to uplifting the social work profession in a positive way and, together with SAASWIPP, strive to inform the public and to raise the profile and improve the image and status of social workers and the profession. They acknowledge that it is social workers themselves, together with the Council, SAASWIPP and the unions, who need to bring about the changes required in the profession.

It is incumbent upon social workers, whether in private practice or not, to continue to improve their perceptions or constructions of their professional selves through ongoing evaluation, learning and actualising of their potential to increase self-respect, so that they in turn may be respected by others. As Anderson (1997:41) puts it:

"Knowledge, including self-knowledge, is a social construction, a product of social exchange and the locus of knowledge lies in the relationship."

\section{BIBLIOGRAPHY}

ANDERSON, H. 1997. Conversation, language and possibilities: A postmodern approach to therapy. New York: Basic Books.

BABBIE, E. 1992. The practice of social research $\left(6^{\text {th }}\right.$ ed $)$. California: Wadsworth.

BLOEM, C.H.M. 2004. 'n Praktykmodel vir privaatpraktykbestuur in maatskaplike werk. Pretoria: University of Pretoria. (Unpublished PhD Thesis)

DE VOS, A.S. (ed), STRYDOM, H., FOUCHE, C.B., POGGENPOEL, M. \& SCHURINK, E.W. 1998. Research at grass roots: A primer for the caring professions. Pretoria: Van Schaik.

DE VOS, A.S., STRYDOM, H., FOUCHE, C.B. \& DELPORT, C.S.L. 2005. Research at grass roots: For the social sciences and human service professions $\left(3^{\text {rd }}\right.$ ed). Pretoria: Van Schaik.

GROBLER, H.D., SCHENCK, C.J. \& DU TOIT, A.S. 2003. Person-centred communication: Theory and practice. Cape Town: Oxford.

EFRAN, J.S., LUKENS, R.J. \& LUKENS, M.D. 1988. Constructivism: What's in it for you? Networker.

FREEMAN, M.L. \& VALENTINE, D.P. 2004. Through the eyes of Hollywood: Images of social workers in film. Social Work, 49(2):151-161.

GIBELMAN, M. 2004. Television and the public image of social workers: Portrayal or betrayal? Social Work, 49(2):331-333.

HAYLEY, T. 2002. The fit between reflecting teams and a social constructionist approach. Journal of Systemic Therapies, 21(1):20-37.

HELD, B.S. 1995. Back to reality: A critique of postmodern theory in psychotherapy. New York: WW Norton.

HENNING, E., VAN RENSBURG, W. \& SMIT, B. 2004. Finding your way in qualitative research. Pretoria: Van Schaik.

HOFFMAN, L. 1990. Constructing realities: an art of lenses. Family Process, 29(1):1-11.

KVALE, S. (ed) 1992. Psychology and postmodernism. London: Sage.

LAYTON, E. \& COLLINS, K. 2004. Advancing through retreating: self-care among helping practitioners. Social Work/Maatskaplike Werk, 40(4):430-444. 
MALHERBE, B.R. \& HENDRIKS, E. 2004. An investigation into the determinants of job satisfaction and the improvement of quality of work life of grassroots social workers. Social Work/Maatskaplike Werk, 40(1):25-40.

MEYER, W.F., MOORE, C. \& VILJOEN, H.G. 1989. Personality theories: From Freud to Frankl. Johannesburg: Lexicon Publishers.

MOUTON, J. \& MARAIS, H.C. 1991. Basic concepts: In the methodology of the social sciences. Pretoria: Human Sciences Research Council.

NEW DICTIONARY OF SOCIAL WORK. 1995 (rev ed). Sv “private practice”. Cape Town: CTP.

REAL, T. 1990. The therapeutic use of self in constructionist/systemic therapy. Family Process, 29:255-270.

ROGERS, C.R. 1951. Client-centred therapy. London: Constable.

ROGERS, C.R. 1978. Carl Rogers on personal powers: Inner strength and its revolutionary impact. London: Constable.

ROWAN, J. 1998. The reality game: A guide to humanistic counselling and psychotherapy $\left(2^{\text {nd }}\right.$ ed). New York: Routledge.

RUBIN, A. \& BABBIE, E. 1993. Research methods for social work ( $2^{\text {nd }}$ ed). California: Brooks/Cole Publishing Company.

SCHENCK, C.J. 2003. Rural social work in South Africa: The perception and experiences of practitioners. Unpublished report, University of South Africa, Pretoria.

THE CONCISE OXFORD DICTIONARY. 1964. Sv "professional”. Great Britain: Oxford.

UNGAR, M. 2004. Surviving as a postmodern social worker: Two ps and three rs of direct practice. Social work, 49(3):488-492.

WATZLAWICK, P. 1984. The invented reality. New York: Norton.

WINSTON, C., STINSON, L. \& STINSON, E. 2004. The public's perception of social work: Is it what we think it is? Social Work, 49(2):164-174.

Mrs Colette Davidson, MA(SS) Mental Health student, UNISA and Prof. Rinie Schenck, Department of Social Work, UNISA, Pretoria, South Africa. 